ISSN 1996-1944

www.mdpi.com/journal/materials

Article

\title{
Factorial Design Approach in Proportioning Prestressed Self-Compacting Concrete
}

\author{
Wu-Jian Long ${ }^{1}$, Kamal Henri Khayat ${ }^{2}$, Guillaume Lemieux ${ }^{3}$, Feng Xing ${ }^{1}$ and Wei-Lun Wang ${ }^{1, *}$ \\ 1 Guangdong Province Key Laboratory of Durability for Marine Civil Engineering, \\ College of Civil Engineering, Shenzhen University, Shenzhen 518060, China; \\ E-Mails: longwj@szu.edu.cn (W.-J.L.); xingf@szu.edu.cn (F.X.) \\ 2 Faculty of Civil, Architectural and Environmental Engineering, \\ Missouri University of Science and Technology, Rolla, MO 65409, USA; \\ E-Mail:khayatk@mst.edu \\ 3 Cement Association of Canada, Montreal, QC J7H 1S7, Canada; E-Mail: glemieux@cement.ca \\ * Author to whom correspondence should be addressed; E-Mail:wang_weilun@hotmail.com; \\ Tel.: +86-755-2695-8863; Fax: +86-755-2653-4021.
}

Academic Editor: Maryam Tabrizian

Received: 2 December 2014 / Accepted: 9 March 2015 / Published: 13 March 2015

\begin{abstract}
In order to model the effect of mixture parameters and material properties on the hardened properties of, prestressed self-compacting concrete (SCC), and also to investigate the extensions of the statistical models, a factorial design was employed to identify the relative significance of these primary parameters and their interactions in terms of the mechanical and visco-elastic properties of SCC. In addition to the 16 fractional factorial mixtures evaluated in the modeled region of -1 to +1 , eight axial mixtures were prepared at extreme values of -2 and +2 with the other variables maintained at the central points. Four replicate central mixtures were also evaluated. The effects of five mixture parameters, including binder type, binder content, dosage of viscosity-modifying admixture (VMA), water-cementitious material ratio $(\mathrm{w} / \mathrm{cm})$, and sand-to-total aggregate ratio $(\mathrm{S} / \mathrm{A})$ on compressive strength, modulus of elasticity, as well as autogenous and drying shrinkage are discussed. The applications of the models to better understand trade-offs between mixture parameters and carry out comparisons among various responses are also highlighted. A logical design approach would be to use the existing model to predict the optimal design, and then run selected tests to quantify the influence of the new binder on the model.
\end{abstract}


Keywords: self-compacting concrete; factorial design; statistical model; model region; mechanical properties; visco-elastic properties

\section{Introduction}

Self-compacting concrete (SCC) is a highly workable concrete that can flow through densely reinforced or geometrically complex structural elements under its own weight and adequately fill voids without segregation or apparent bleeding, requiring no vibration for its consolidation [1-3]. Successful use of SCC in precast, prestressed and cast-in-place applications worldwide may help in the construction of longer-lived and more cost-effective structures [4-10].

Although the mix design of concrete is critical to its workability and performance, adequate selection of material constituents is a key factor in the optimization process of a concrete mixture that can achieve adequate performance and service life [11,12]. Material characteristics and mix design of SCC have a marked effect on all aspects of SCC production and placement, and on the fresh and hardened properties of the concrete $[13,14]$. The proportioning of SCC often involves the adjustment of several mixture parameters to achieve a compromise between the properties in its fresh and hardened states [15]. While certain design methods and mathematical approaches for SCC have been published [16-26], a lack of adequate research studies warrants investigation of SCC designated for prestressed applications.

In order to better understand the influence of key mix design parameters and material constituents on the behaviour of SCC, and also to investigate the extensions of the statistical models, a fractional factorial design was used to identify the relative significance of these primary parameters and their interactions with the mechanical and visco-elastic properties of prestressed SCC. A total of 28 SCC mixture combinations were used in the experimental design. It is important to note that the research work presented herein is an extension of the previous experimental plan presented by the authors [15]. The applications of the models to better understand trade-offs between mixture parameters and carry out comparisons among various responses are also highlighted. Better understanding of these parameters and their effects on the performance of SCC designated for prestressed applications and knowledge of trade-offs among the various mixture parameters on various properties of such concrete could simplify the test protocol needed to optimize SCC given a certain set of performance requirements, and therefore it is essential for successful development of prestressed SCC.

\section{Experimental Program}

\subsection{Fractional Factorial Design}

As shown in Table 1, a total of 28 SCC mixture combinations were used in the experimental design. A $2^{5-1}$ fractional factorial design was used to evaluate the influence of mixture proportioning and constituent material characteristics on the hardened properties of SCC. By definition, 2 is the number of levels of each factor investigated, 5 is the number of factors investigated, and 1 is the size of the fraction of the full factorial used. The first 16 mixtures for the fractional factorial plan were set at coded values of -1 and +1 . The $2^{5-1}$ fractional factorial design was then expanded to include eight 
additional mixtures (axial mixtures) where each variable was adjusted separately at the extreme $\alpha$ value of -2 and +2 with the other variables maintained at the central points (0). This is done to extend the model's values for the five principle variables and consider the quadratic effects for each variable. Four replicate central mixtures were also prepared to estimate the degree of the experimental error for the modeled responses.

Table 1. Details of experimental program.

\begin{tabular}{|c|c|c|c|c|c|c|c|c|c|c|c|c|}
\hline \multirow{2}{*}{\multicolumn{2}{|c|}{ Type }} & \multirow{2}{*}{$\begin{array}{l}\text { Mix } \\
\text { No. }\end{array}$} & \multicolumn{5}{|c|}{ Coded Values } & \multicolumn{5}{|c|}{ Absolute Values } \\
\hline & & & Binder & $\mathbf{w} / \mathbf{c m}$ & VMA * & $\begin{array}{c}\text { Binder } \\
\text { Type }\end{array}$ & $\mathbf{S} / \mathbf{A} * *$ & $\begin{array}{l}\text { Binder } \\
\left(\mathrm{kg} / \mathrm{m}^{3}\right)\end{array}$ & $\mathbf{w} / \mathbf{c m}$ & $\begin{array}{l}\text { VMA (mL/ } \\
100 \mathrm{~kg} \mathrm{CM})\end{array}$ & $\begin{array}{c}\text { Binder } \\
\text { Type }\end{array}$ & $\begin{array}{l}\text { S/A } \\
(\%) \\
\end{array}$ \\
\hline \multirow{28}{*}{ 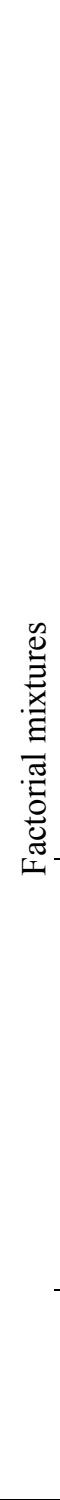 } & \multirow{16}{*}{ 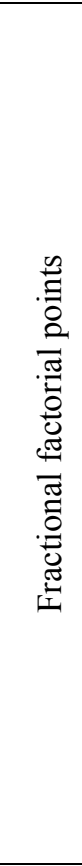 } & 1 & -1 & -1 & -1 & -1 & 1 & 440 & 0.34 & 0 & MS & 0.54 \\
\hline & & 2 & -1 & -1 & -1 & 1 & -1 & 440 & 0.34 & 0 & $\mathrm{HE} * * *$ & 0.46 \\
\hline & & 3 & -1 & -1 & 1 & -1 & -1 & 440 & 0.34 & 100 & MS & 0.46 \\
\hline & & 4 & -1 & -1 & 1 & 1 & 1 & 440 & 0.34 & 100 & $\mathrm{HE}$ & 0.54 \\
\hline & & 5 & -1 & 1 & -1 & -1 & -1 & 440 & 0.40 & 0 & MS & 0.46 \\
\hline & & 6 & -1 & 1 & -1 & 1 & 1 & 440 & 0.40 & 0 & $\mathrm{HE}$ & 0.54 \\
\hline & & 7 & -1 & 1 & 1 & -1 & 1 & 440 & 0.40 & 100 & MS & 0.54 \\
\hline & & 8 & -1 & 1 & 1 & 1 & -1 & 440 & 0.40 & 100 & $\mathrm{HE}$ & 0.46 \\
\hline & & 9 & 1 & -1 & -1 & -1 & -1 & 500 & 0.34 & 0 & MS & 0.46 \\
\hline & & 10 & 1 & -1 & -1 & 1 & 1 & 500 & 0.34 & 0 & $\mathrm{HE}$ & 0.54 \\
\hline & & 11 & 1 & -1 & 1 & -1 & 1 & 500 & 0.34 & 100 & MS & 0.54 \\
\hline & & 12 & 1 & -1 & 1 & 1 & -1 & 500 & 0.34 & 100 & HE & 0.46 \\
\hline & & 13 & 1 & 1 & -1 & -1 & 1 & 500 & 0.40 & 0 & MS & 0.54 \\
\hline & & 14 & 1 & 1 & -1 & 1 & -1 & 500 & 0.40 & 0 & $\mathrm{HE}$ & 0.46 \\
\hline & & 15 & 1 & 1 & 1 & -1 & -1 & 500 & 0.40 & 100 & MS & 0.46 \\
\hline & & 16 & 1 & 1 & 1 & 1 & 1 & 500 & 0.40 & 100 & $\mathrm{HE}$ & 0.54 \\
\hline & \multirow{8}{*}{ 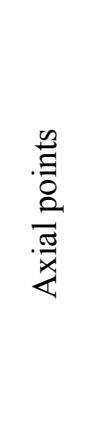 } & A1 & -2 & 0 & 0 & 0 & 0 & 410 & 0.37 & 50 & MS-HE & 0.50 \\
\hline & & A2 & 2 & 0 & 0 & 0 & 0 & 530 & 0.37 & 50 & MS-HE & 0.50 \\
\hline & & A3 & 0 & -2 & 0 & 0 & 0 & 470 & 0.31 & 50 & MS-HE & 0.50 \\
\hline & & A4 & 0 & 2 & 0 & 0 & 0 & 470 & 0.43 & 50 & MS-HE & 0.50 \\
\hline & & A5 & 0 & 0 & -2 & 0 & 0 & 470 & 0.37 & 0 & MS-HE & 0.50 \\
\hline & & A6 & 0 & 0 & 2 & 0 & 0 & 470 & 0.37 & 150 & MS-HE & 0.50 \\
\hline & & A7 & 0 & 0 & 0 & 0 & -2 & 470 & 0.37 & 50 & MS-HE & 0.42 \\
\hline & & A8 & 0 & 0 & 0 & 0 & 2 & 470 & 0.37 & 50 & MS-HE & 0.58 \\
\hline & \multirow{4}{*}{ 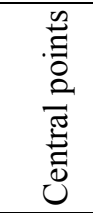 } & $\mathrm{C} 1$ & 0 & 0 & 0 & 0 & 0 & 470 & 0.37 & 50 & MS-HE & 0.50 \\
\hline & & $\mathrm{C} 2$ & 0 & 0 & 0 & 0 & 0 & 470 & 0.37 & 50 & MS-HE & 0.50 \\
\hline & & $\mathrm{C} 3$ & 0 & 0 & 0 & 0 & 0 & 470 & 0.37 & 50 & MS-HE & 0.50 \\
\hline & & $\mathrm{C} 4$ & 0 & 0 & 0 & 0 & 0 & 470 & 0.37 & 50 & MS-HE & 0.50 \\
\hline
\end{tabular}

* Thickening-type viscosity-modifying admixture (VMA); ** Crushed aggregate with MSA (maximum size of aggregate) of $12.5 \mathrm{~mm}$ and natural sand; *** Type HE cement $+20 \%$ Class F fly ash.

The five modeled mixture parameters included the binder content (BC), binder type (BT), water-to-cementitious materials ratio $(\mathrm{w} / \mathrm{cm})$, dosage of thickening-type viscosity modifying admixture (VMA), and volume of the sand-to-total aggregate ratio (S/A). The experimental modeled region is illustrated in Figure 1. The modeled responses within the model region of -2 to +2 include 
compressive strength, modulus of elasticity, as well as autogenous and drying shrinkage. It is important to note that the objective of enlarging the statistical models to -2 and +2 is to attempt to improve the quality of the models and consider any quadratic effects of certain variables.

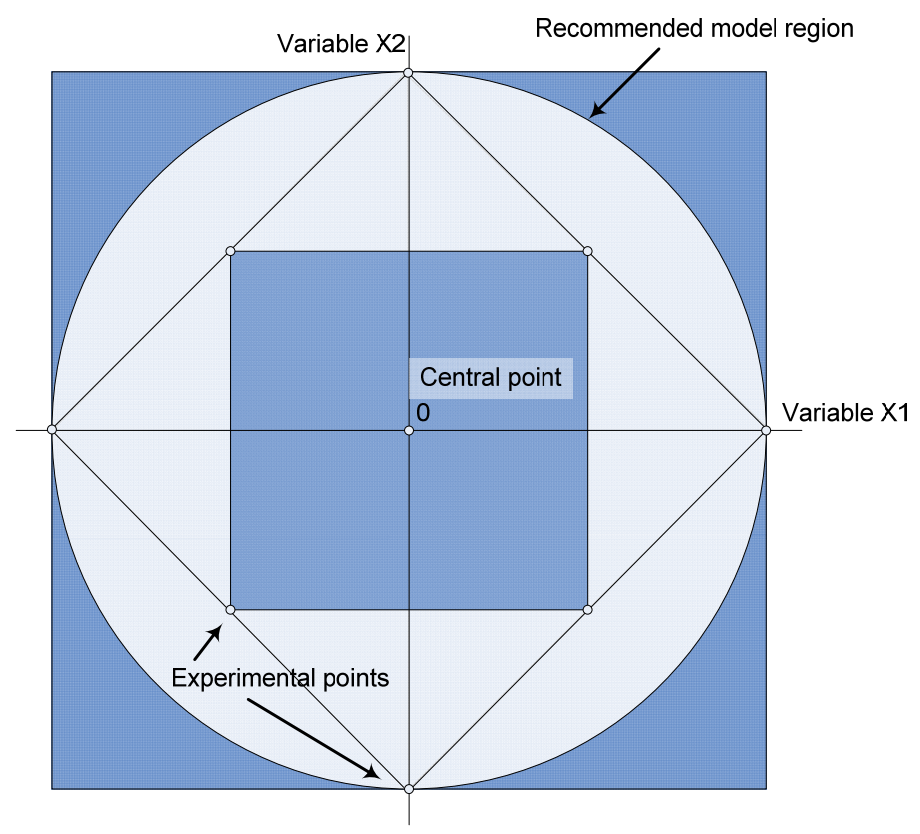

Figure 1. Presentation of modeled region.

The coded and absolute values used for the factorial design are presented in Table 1. The coded values are calculated as the difference between the absolute values and values corresponding to the central points, divided by the spread between the absolute values corresponding to 0 and 1 , as shown below:

Coded BC $=($ absolute $\mathrm{BC}-470) / 30$

Coded $\mathrm{w} / \mathrm{cm}=($ absolute $\mathrm{w} / \mathrm{cm}-0.37) / 0.03$

Coded VMA $=($ absolute VMA-50) $/ 50$

Coded $\mathrm{S} / \mathrm{A}=($ absolute $\mathrm{S} / \mathrm{A}-0.50) / 0.04$

The statistical models are valid for mixtures between -2 and +2 consisting of mixtures with a w/cm of 0.31 to 0.43 , binder content from 410 to $530 \mathrm{~kg} / \mathrm{m}^{3}$, VMA of 0 to $150 \mathrm{~mL} / 100 \mathrm{~kg} \mathrm{CM}$ (cementitious material), and S/A between 0.42 and 0.58 , by volume. The ranges of these variables were selected to cover a wide scope of mixture ingredients. The choices of the $\mathrm{w} / \mathrm{cm}$ and binder type were based on the results obtained in the previous parametric study [11]. A low w/cm was included to secure superior mechanical performance and the higher w/cm for better workability. Type HE (high early strength) binder with $20 \%$ Class F fly ash replacement was chosen given its better overall performance in terms of workability and compressive strength development compared to SCC made with Type HE binder with 30\% slag [11]. The coarse aggregate employed for the experimental design was crushed aggregate with a maximum size of coarse aggregate (MSA) of $12.5 \mathrm{~mm}$. This aggregate was shown to offer better performance in terms of workability and strength development than gravel of similar MSA or crushed aggregate with MSA 9.5 or $19 \mathrm{~mm}$ [11]. 
Factorial designs are made to test two or more factors at the same time. This is done by comparing the results obtained with different levels of each factor. The major benefit of using this approach is to find the combined effects of various parameters [27].

\subsection{Materials Characteristics}

Two types of Portland cement, Type MS (Moderate Sulfate) and Type HE, and a Class F fly ash were used in this investigation. The specific gravities of the MS cement, HE cement, and fly ash are $3.14,3.15$, and 2.53, respectively, and their Blaine fineness values are 390,530 , and $410 \mathrm{~m}^{2} / \mathrm{kg}$, respectively. The SCC mixtures were evaluated using Type MS cement without any fly ash, as well as Type HE cement with 20\% Class F fly ash replacement, by mass.

All concrete mixtures were prepared with crushed aggregate with a $12.5 \mathrm{~mm}$ MSA. Natural siliceous sand with a specific gravity of 2.66 conforming to AASHTO T 27 specifications was used [28]. The particle-size distribution of the sand and coarse aggregate are within the AASHTO recommended limits.

A polycarboxylate-based HRWRA (high-range water-reducing admixture) complying with ASTM C494C/C494M (Type F) and an organic, thickening-type VMA were used in the SCC mixtures [29]. The specific gravities of these admixtures are 1.047 and 1.0, respectively, and their solid contents are $20.3 \%$ and $6 \%$, respectively.

\subsection{Mixing Sequence}

The SCC mixtures were prepared using a drum mixer. The mixing sequence consisted of wetting the sand and coarse aggregate with half of the mixing water, followed by the addition of the binder. The initial wetting of the aggregate was carried out to ensure that the aggregate could later be coated by a layer of cement paste that would enhance the quality of the interface between the aggregate and hydrated cement paste. The HRWRA and VMA diluted with the remaining mixing water were then introduced over $30 \mathrm{~s}$, and the concrete was mixed for $2.5 \mathrm{~min}$, as shown in Figure 2. The concrete remained at rest in the mixer for 2 min for fluidity adjustment and to enable any large air bubbles trapped during mixing to rise to the surface.

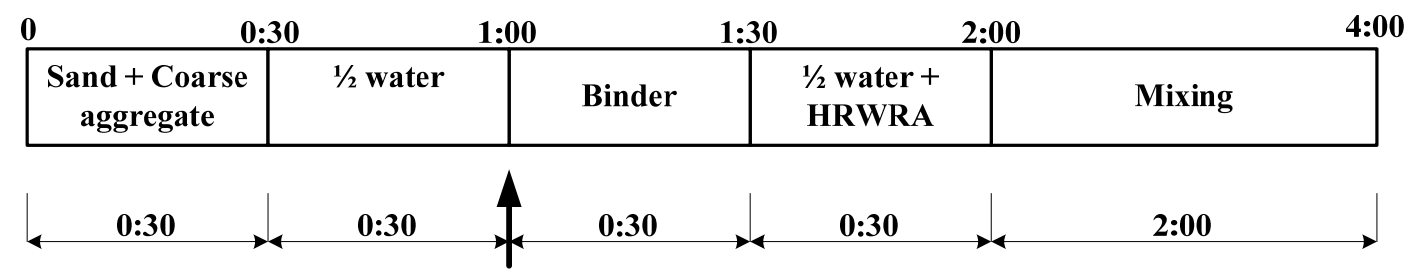

Figure 2. Standard mixing sequence.

\subsection{Test Methods}

Concrete cylinders measuring $100 \times 200 \mathrm{~mm}$ and $150 \times 300 \mathrm{~mm}$ were sampled $10 \mathrm{~min}$ after the end of mixing according to ASTM C192-14/C192M-14, to evaluate compressive strength, modulus of elasticity, and autogenous and drying shrinkage under three different curing conditions summarized in Table 2 [30-33]. The samples used to determine compressive strength and elastic modulus were air-cured and steam-cured for the first $18 \mathrm{~h}$, and also moist-cured for 7, 28, and 56 days. 
Table 2. Curing conditions.

\begin{tabular}{ccc}
\hline Curing Method & Stage & Detail \\
\hline & I & Ambient temperature for $2 \mathrm{~h}$ after water-cement contact \\
& II & Temperature raised for $2 \mathrm{~h}$ \\
Steam-curing & III & Concrete temperature maintained for $10 \mathrm{~h}$ \\
& IV & Temperature decreases over $2 \mathrm{~h}$ to ambient temperature \\
& V & Air-curing until age of testing at $18 \mathrm{~h}$ \\
\hline \multirow{2}{*}{ Moist-curing } & I & $18 \mathrm{~h}$ in molds with wet burlap at $23 \pm 2{ }^{\circ} \mathrm{C}$ \\
& II & Moist-cured at $23 \pm 2{ }^{\circ} \mathrm{C}$ until testing age \\
\hline \multirow{2}{*}{ Air-curing } & I & $18 \mathrm{~h}$ in molds with wet burlap at $23 \pm 2{ }^{\circ} \mathrm{C}$ \\
& II & Air-dried at $23 \pm 2{ }^{\circ} \mathrm{C}$ until testing age \\
\hline
\end{tabular}

All sampled specimens were cast without any mechanical consolidation. Some of the samples were covered and remained in the laboratory at $23 \pm 2{ }^{\circ} \mathrm{C}$ to air cure until the time of testing, while others were steam-cured according to the regime described in Figure 3. Based on the AASHTO (American Association of State Highway and Transportation Officials), CSA (Canadian Standards Association), and PCI (Precast/Prestressed Concrete Institute) specifications, the maximum curing temperature in the concrete should not exceed $70{ }^{\circ} \mathrm{C}$ to prevent the occurrence of delayed ettringite formation [34-36]. The standards also stipulate that the increase in temperature-time ratio should not exceed 22 and $20^{\circ} \mathrm{C} / \mathrm{h}$ (depending on the standard), and the decrease in temperature-time ratio should be lower than 22 and $15^{\circ} \mathrm{C} / \mathrm{h}$ for the AASHTO and CSA, respectively.

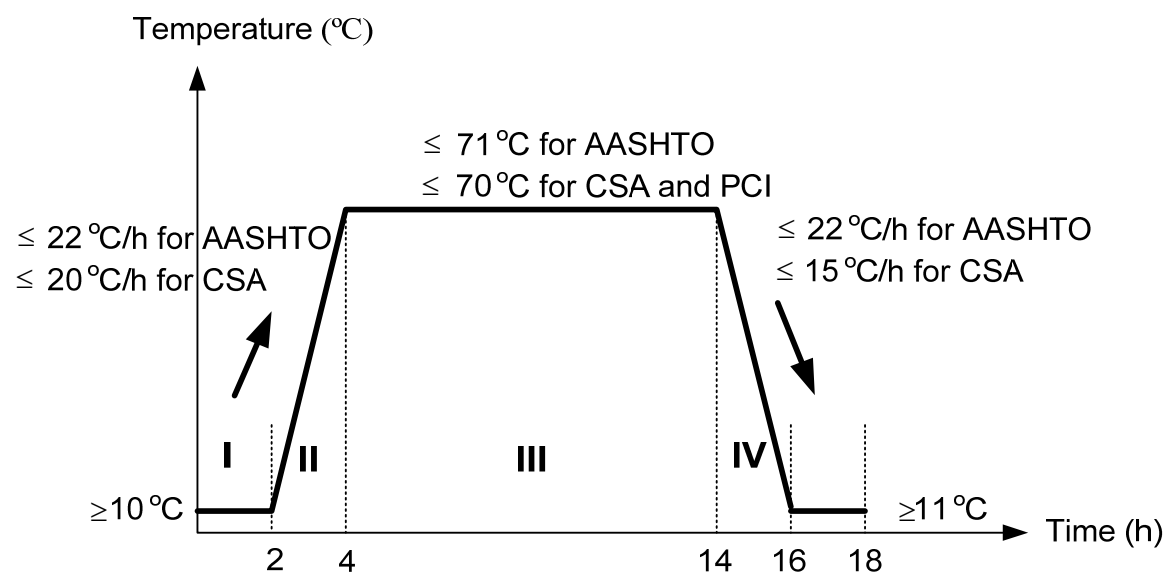

Figure 3. Steam curing regime specified by AASHTO and CSA.

All of the investigated mixtures considered in the experimental design had an initial slump flow of $680 \pm 20 \mathrm{~mm}$ that was obtained by adjusting the dosage rate of the high-range water reducing admixture (HRWRA). The targeted release compressive strength after $18 \mathrm{~h}$ of steam curing and 56-day of moist curing were $35 \mathrm{MPa}$ and 55 to $70 \mathrm{MPa}$, respectively. The compressive strength was determined on $100 \times 200 \mathrm{~mm}$ cylinders. For 56-day compressive strength, the specimens were stored at $100 \%$ relative humidity and $23 \pm 2{ }^{\circ} \mathrm{C}$ until the time of testing. In addition to compressive strength, samples were subjected to steam curing to determine the 18 -h modulus of elasticity and to initiate shrinkage testing at the prestress release time. The compressive strengths and the modulus of elasticity of the tested SCC at various ages are presented in Tables 3 and 4, respectively. 
Autogenous shrinkage was measured on prisms measuring $75 \times 75 \times 285 \mathrm{~mm}$. The prisms were sealed immediately after removal from the molds at $18 \mathrm{~h}$ of age and kept at $23 \pm 2{ }^{\circ} \mathrm{C}$ until the end of testing. Autogenous shrinkage was monitored using embedded vibrating wire strain gauges until stabilization.

Six $150 \times 300 \mathrm{~mm}$ cylindrical test specimens were cast to monitor drying shrinkage. The specimens were steam cured until the age of $16 \mathrm{~h}$ and were then demolded. The ends of the cylinders were ground, and external studs were installed for deformation measurements. A digital-type extensometer was used to determine drying shrinkage. Drying shrinkage testing started at the age of $18 \mathrm{~h}$. Shrinkage specimens were kept in a temperature-controlled room at $23 \pm 2{ }^{\circ} \mathrm{C}$ and $50 \% \pm 4 \%$ relative humidity. Drying shrinkage deformations were monitored for 11 months. The detailed autogenous and drying shrinkage values at various ages are given in Table 5.

Table 3. Compressive strength of the tested SCC (MPa).

\begin{tabular}{|c|c|c|c|c|c|}
\hline \multirow{2}{*}{\multicolumn{2}{|c|}{ Mix ID }} & \multirow{2}{*}{$\begin{array}{c}18 \mathrm{~h} \\
\text { Steam-Cured }\end{array}$} & 7 Days & \multirow{2}{*}{$\frac{28 \text { Days }}{\text { Moist-Cured }}$} & \multirow[t]{2}{*}{56 Days } \\
\hline & & & & & \\
\hline \multirow{16}{*}{ 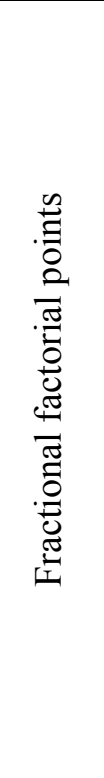 } & 1 & 36.8 & 54.2 & 58.8 & 60.7 \\
\hline & 2 & 33.0 & 48.0 & 59.2 & 62.5 \\
\hline & 3 & 38.0 & 54.6 & 60.4 & 69.6 \\
\hline & 4 & 31.5 & 51.6 & 60.2 & 65.3 \\
\hline & 5 & 31.9 & 44.6 & 51.2 & 53.2 \\
\hline & 6 & 33.3 & 46.2 & 54.2 & 61.0 \\
\hline & 7 & 28.1 & 41.5 & 49.8 & 55.7 \\
\hline & 8 & 31.8 & 49.6 & 56.3 & 66.9 \\
\hline & 9 & 35.1 & 51.7 & 62.2 & 68.2 \\
\hline & 10 & 33.8 & 55.7 & 64.8 & 78.0 \\
\hline & 11 & 36.6 & 57.5 & 64.5 & 69.1 \\
\hline & 12 & 33.5 & 57.7 & 70.2 & 75.4 \\
\hline & 13 & 31.8 & 44.9 & 51.2 & 58.2 \\
\hline & 14 & 30.9 & 40.4 & 55.2 & 60.9 \\
\hline & 15 & 30.1 & 37.6 & 47.5 & 55.4 \\
\hline & 16 & 28.1 & 39.0 & 47.6 & 53.2 \\
\hline \multirow{8}{*}{ 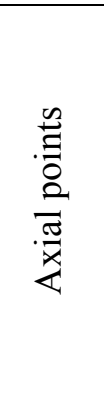 } & A1 & 30.6 & 55.3 & 66.6 & 70.7 \\
\hline & A2 & 37.6 & 50.3 & 59.4 & 65.2 \\
\hline & A3 & 8.5 & 65.9 & 75.8 & 81.5 \\
\hline & A4 & 29.4 & 39.9 & 48.7 & 53.4 \\
\hline & A5 & 30.4 & 53.7 & 63.7 & 69.0 \\
\hline & A6 & 33.0 & 53.9 & 61.1 & 68.8 \\
\hline & A7 & 36.0 & 52.9 & 63.3 & 66.1 \\
\hline & A8 & 35.6 & 49.5 & 60.1 & 63.7 \\
\hline \multirow{4}{*}{ 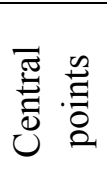 } & $\mathrm{C} 1$ & 36.0 & 52.7 & 65.0 & 71.6 \\
\hline & $\mathrm{C} 2$ & 36.0 & 52.0 & 64.2 & 71.7 \\
\hline & $\mathrm{C} 3$ & 36.5 & 54.3 & 63.8 & 69.2 \\
\hline & $\mathrm{C} 4$ & 35.1 & 51.1 & 62.1 & 69.1 \\
\hline
\end{tabular}


Table 4. Modulus of elasticity and HRWRA demand of the tested SCC.

\begin{tabular}{|c|c|c|c|c|c|}
\hline \multirow{2}{*}{\multicolumn{2}{|c|}{ Mix ID }} & \multirow{3}{*}{$\begin{array}{c}\frac{18 \mathrm{~h}}{\text { Steam-Cured }} \\
\mathrm{GPa}\end{array}$} & 28 Days & 56 Days & \multirow{3}{*}{$\begin{array}{c}\text { HRWRA Demand } \\
\text { L/100 kg CM }\end{array}$} \\
\hline & & & \multicolumn{2}{|c|}{ Moist-Cured } & \\
\hline & & & GPa & GPa & \\
\hline \multirow{16}{*}{ 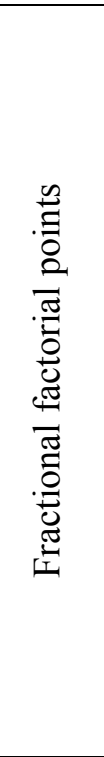 } & 1 & 33.0 & 37.0 & 39.5 & 2.23 \\
\hline & 2 & 31.0 & 39.0 & 41.5 & 2.73 \\
\hline & 3 & 34.0 & 41.0 & 42.5 & 2.39 \\
\hline & 4 & 29.0 & 37.5 & 38.0 & 2.95 \\
\hline & 5 & 30.0 & 34.5 & 36.5 & 0.77 \\
\hline & 6 & 29.5 & 35.5 & 38.0 & 1.20 \\
\hline & 7 & 30.5 & 34.0 & 34.0 & 0.86 \\
\hline & 8 & 31.0 & 37.5 & 39.0 & 1.41 \\
\hline & 9 & 32.5 & 39.5 & 41.0 & 1.80 \\
\hline & 10 & 31.5 & 39.0 & 40.5 & 2.00 \\
\hline & 11 & 33.0 & 38.0 & 39.0 & 2.00 \\
\hline & 12 & 34.5 & 41.0 & 41.5 & 2.00 \\
\hline & 13 & 28.5 & 34.0 & 35.0 & 0.50 \\
\hline & 14 & 27.5 & 37.0 & 38.5 & 1.02 \\
\hline & 15 & 28.0 & 34.0 & 35.0 & 0.70 \\
\hline & 16 & 24.0 & 32.5 & 33.5 & 1.00 \\
\hline \multirow{8}{*}{ 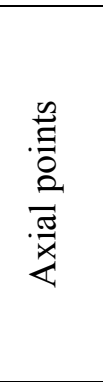 } & A1 & 30.5 & 38.0 & 40.0 & 1.13 \\
\hline & $\mathrm{A} 2$ & 28.0 & 35.0 & 35.5 & 2.47 \\
\hline & A3 & 18.5 & 40.0 & 41.0 & 3.95 \\
\hline & A4 & 27.0 & 32.5 & 34.5 & 0.70 \\
\hline & A5 & 28.0 & 37.5 & 37.5 & 1.67 \\
\hline & A6 & 30.5 & 35.5 & 38.5 & 1.73 \\
\hline & A7 & 29.5 & 36.0 & 38.5 & 1.43 \\
\hline & A 8 & 30.0 & 35.5 & 37.0 & 1.53 \\
\hline \multirow{4}{*}{ 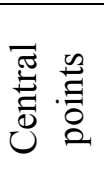 } & $\mathrm{C} 1$ & 28.5 & 37.0 & 38.5 & 1.73 \\
\hline & $\mathrm{C} 2$ & 30.0 & 37.5 & 39.5 & 1.73 \\
\hline & C3 & 29.0 & 38.5 & 39.5 & 1.73 \\
\hline & $\mathrm{C} 4$ & 30.0 & 38.5 & 38.5 & 1.73 \\
\hline
\end{tabular}

\section{Results and Discussion}

\subsection{Derived Statistical Models for Mechanical Properties}

Statistical models were established by multi-regression analyses. Mean values and standard deviations for each of the responses and calculated relative errors corresponding to $90 \%$ confidence limits are summarized in Table 6.

The coefficient and probality (Prob.) $>|\mathbf{t}|$ values of the derived models for compressive strength and modulus of elasticity (MOE) are presented in Table 7. The estimate for each factor refers to the contribution of that factor to the modeled response. Probability values less than 0.1 were considered significant evidence that the factor has a significant influence on the modeled response. Student tests were run to evaluate the significance of the model factors and their second-order interactions on a given response. For each modeled response, the single-operator relative error corresponding to a $90 \%$ confidence limit was used to perform the significance evaluation. Single-operator relative errors were determined using a mixture corresponding to the central point of the experimental design. 
Table 5. Autogenous and drying shrinkage values at various ages ( $\mu$ strain).

\begin{tabular}{|c|c|c|c|c|c|c|c|}
\hline \multirow{2}{*}{\multicolumn{2}{|c|}{ Mixture ID }} & \multicolumn{2}{|c|}{ Autogenous Shrinkage } & \multicolumn{4}{|c|}{ Drying Shrinkage } \\
\hline & & 7 Days & 28 Days & 7 Days & 28 Days & 112 Days & 250 Days \\
\hline \multirow{16}{*}{ 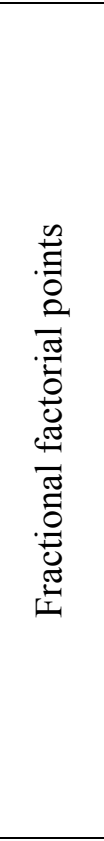 } & 1 & 75 & 105 & 270 & 465 & 720 & 830 \\
\hline & 2 & 250 & 265 & 180 & 310 & 435 & 535 \\
\hline & 3 & 85 & 115 & 160 & 270 & 450 & 565 \\
\hline & 4 & 205 & 260 & 240 & 365 & 615 & 735 \\
\hline & 5 & 35 & 90 & 80 & 130 & 330 & 495 \\
\hline & 6 & 95 & 190 & 130 & 230 & 475 & 545 \\
\hline & 7 & 50 & 100 & 80 & 195 & 440 & 585 \\
\hline & 8 & 130 & 245 & 160 & 270 & 570 & 670 \\
\hline & 9 & 130 & 155 & 290 & 550 & 820 & 975 \\
\hline & 10 & 245 & 315 & 315 & 540 & 765 & 930 \\
\hline & 11 & 150 & 230 & 185 & 255 & 530 & 680 \\
\hline & 12 & 190 & 305 & 235 & 330 & 540 & 635 \\
\hline & 13 & 70 & 110 & 140 & 225 & 540 & 690 \\
\hline & 14 & 70 & 140 & 150 & 280 & 555 & 640 \\
\hline & 15 & 65 & 100 & 100 & 190 & 405 & 545 \\
\hline & 16 & 75 & 170 & 150 & 380 & 620 & 720 \\
\hline \multirow{8}{*}{ 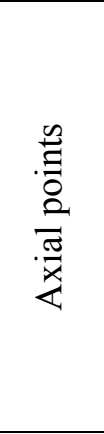 } & $\mathrm{A} 1$ & 135 & 220 & 140 & 295 & 420 & 520 \\
\hline & $\mathrm{A} 2$ & 125 & 230 & 175 & 390 & 550 & 660 \\
\hline & $\mathrm{A} 3$ & 180 & 225 & 215 & 355 & 450 & 515 \\
\hline & A4 & 70 & 140 & 165 & 375 & 555 & 675 \\
\hline & A5 & 145 & 220 & 150 & 275 & 430 & 565 \\
\hline & A6 & 120 & 165 & 160 & 330 & 460 & 575 \\
\hline & A7 & 125 & 200 & 215 & 350 & 470 & 565 \\
\hline & A 8 & 115 & 190 & 190 & 350 & 490 & 590 \\
\hline \multirow{4}{*}{ 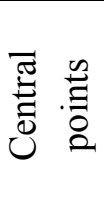 } & $\mathrm{C} 1$ & 120 & 200 & 190 & 330 & 500 & 615 \\
\hline & $\mathrm{C} 2$ & 115 & 200 & 230 & 340 & 515 & 620 \\
\hline & C3 & 110 & 200 & 190 & 370 & 520 & 615 \\
\hline & $\mathrm{C} 4$ & 120 & 200 & 180 & 345 & 495 & 620 \\
\hline
\end{tabular}

Table 6. Mean values and relative errors of central points ( $90 \%$ confidence limit).

\begin{tabular}{cccc}
\hline Property & Mean & $\begin{array}{c}\text { Standard } \\
\text { Deviation }\end{array}$ & $\begin{array}{c}\text { Relative Error * in 90\% } \\
\text { Confidence Limit, (\%) }\end{array}$ \\
\hline 18 h compressive strength, MPa & 35.9 & 0.583 & 1.9 \\
28 days compressive strength, MPa & 63.8 & 1.223 & 2.3 \\
56 days compressive strength, MPa & 70.4 & 1.445 & 2.4 \\
18 h modulus of elasticity, GPa & 29.4 & 0.750 & 3.0 \\
28 days modulus of elasticity, GPa & 37.9 & 0.750 & 2.3 \\
56 days modulus of elasticity, GPa & 39.0 & 0.550 & 1.7 \\
\hline
\end{tabular}

* Relative error $=2.35 \frac{\sigma}{\bar{x} \sqrt{n}} \cdot 100(\%)$; where, $2.35=$ coefficient representing the $90 \%$ confidence interval for the Student distribution for $n=4 ; \sigma=$ standard deviation; $n=$ number of observations; $\bar{x}=$ mean value of observations. 
Table 7. Parameter estimates of derived models for mechanical properties.

\begin{tabular}{|c|c|c|c|c|c|c|}
\hline \multirow{3}{*}{$\begin{array}{c}\text { Property } \\
\text { Model Type } \\
\text { Parameters }\end{array}$} & \multicolumn{2}{|c|}{ 7-Day $f_{c}^{\prime}$, MPa $R^{2}=0.76$} & \multicolumn{2}{|c|}{ 28-Day $f_{c}^{\prime}$, MPa $R^{2}=\mathbf{0 . 7 2}$} & \multicolumn{2}{|c|}{ 56-Day $f_{c}^{\prime}$, MPa $R^{2}=\mathbf{0 . 7 9}$} \\
\hline & \multicolumn{2}{|c|}{ Linear Model } & \multicolumn{2}{|c|}{ Linear Model } & \multicolumn{2}{|c|}{ Linear Model } \\
\hline & Estimates & Prob. $>|\mathbf{t}|$ & Estimates & Prob. $>|t|$ & Estimates & Prob. $>|\mathbf{t}|$ \\
\hline Intercept & +50.25 & - & +59.62 & - & +65.43 & - \\
\hline Binder content & $\mathrm{NS} *$ & NS & NS & NS & NS & NS \\
\hline $\mathrm{w} / \mathrm{cm}$ & -5.80 & 0.001 & -5.90 & 0.001 & -5.85 & 0.001 \\
\hline VMA & NS & NS & NS & NS & NS & NS \\
\hline Binder type & NS & NS & +1.50 & 0.061 & +2.52 & 0.006 \\
\hline $\mathrm{S} / \mathrm{A}$ & NS & NS & NS & NS & NS & NS \\
\hline $\mathrm{BC} \cdot \mathrm{w} / \mathrm{cm}$ & -2.13 & 0.017 & -2.08 & 0.035 & -2.60 & 0.018 \\
\hline $\mathrm{BC} \cdot \mathrm{VMA}$ & NS & NS & NS & NS & -2.02 & 0.062 \\
\hline $\mathrm{w} / \mathrm{cm} \cdot \mathrm{BT}$ & NS & NS & NS & NS & NS & NS \\
\hline Property & \multicolumn{2}{|c|}{ 18-h MOE, GPa (Steam-Cured) $R^{2}=0.73$} & \multicolumn{2}{|c|}{ 28-Day MOE, GPa $R^{2}=0.75$} & \multicolumn{2}{|c|}{ 56-Day MOE, GPa $R^{2}=0.85$} \\
\hline Model Type & \multicolumn{2}{|c|}{ Linear Model } & \multicolumn{2}{|c|}{ Linear Model } & \multicolumn{2}{|c|}{ Linear Model } \\
\hline Parameters & Estimates & Prob. $>|\mathbf{t}|$ & Estimates & Prob. $>|t|$ & Estimates & Prob. $>|t|$ \\
\hline Intercept & +29.92 & - & +36.83 & - & +38.24 & - \\
\hline Binder content & -0.56 & 0.040 & -0.29 & 0.100 & -0.55 & 0.014 \\
\hline $\mathrm{w} / \mathrm{cm}$ & -1.48 & 0.001 & -2.00 & 0.001 & -1.97 & 0.001 \\
\hline Binder type & -0.40 & 0.100 & +0.50 & 0.051 & +0.57 & 0.012 \\
\hline S/A & NS & NS & -0.71 & 0.008 & -0.89 & 0.001 \\
\hline $\mathrm{BC} \cdot \mathrm{w} / \mathrm{cm}$ & -1.09 & 0.002 & NS & NS & NS & NS \\
\hline $\mathrm{w} / \mathrm{cm} \cdot \mathrm{BT}$ & NS & NS & NS & NS & +0.54 & 0.045 \\
\hline $\mathrm{VMA} \cdot \mathrm{S} / \mathrm{A}$ & -0.78 & 0.020 & NS & NS & -0.52 & 0.055 \\
\hline $\mathrm{BT} \cdot \mathrm{S} / \mathrm{A}$ & -0.66 & 0.050 & NS & NS & NS & NS \\
\hline
\end{tabular}

* NS: Not significant.

The derived models are summarized in Table 8 with the mixture variables expressed as coded values. The models are expressed as the factors with the highest influence on the modeled responses list in descending order. A negative estimate signifies that an increase in the modeled parameters results in a reduction in the measured response. For example, in the case of 7-day compressive strength model, an increase in $\mathrm{w} / \mathrm{cm}$ is expected to decrease the 7-day compressive strength.

Table 8. Derived statistical models for mechanical properties.

\begin{tabular}{|c|c|c|c|}
\hline Property & Age & Derived Equations & $R^{2}$ \\
\hline \multirow{3}{*}{$\begin{array}{l}\text { Compressive } \\
\text { strength, } \mathrm{MPa}\end{array}$} & 7 days & $+50.25-5.80 \mathrm{w} / \mathrm{cm}-2.13(\mathrm{BC} \cdot \mathrm{w} / \mathrm{cm})$ & 0.76 \\
\hline & 28 days & $+59.62-5.90 \mathrm{w} / \mathrm{cm}+1.50 \mathrm{BT}-2.08(\mathrm{BC} \cdot \mathrm{w} / \mathrm{cm})$ & 0.72 \\
\hline & 56 days & $+65.43-5.85 \mathrm{w} / \mathrm{cm}+2.52 \mathrm{BT}-2.60(\mathrm{BC} \cdot \mathrm{w} / \mathrm{cm})-2.02(\mathrm{BC} \cdot \mathrm{VMA})$ & 0.79 \\
\hline \multirow{3}{*}{$\begin{array}{l}\text { Modulus of } \\
\text { elasticity, GPa }\end{array}$} & $18 \mathrm{~h}$ & $\begin{array}{c}+29.92-1.48 \mathrm{w} / \mathrm{cm}-0.56 \mathrm{BC}-0.40 \mathrm{BT}-1.09(\mathrm{BC} \cdot \mathrm{w} / \mathrm{cm}) \\
-0.78(\mathrm{VMA} \cdot \mathrm{S} / \mathrm{A})-0.66(\mathrm{BT} \cdot \mathrm{S} / \mathrm{A})\end{array}$ & 0.73 \\
\hline & 28 day & $+36.83-2.00 \mathrm{w} / \mathrm{cm}-0.71 \mathrm{~S} / \mathrm{A}+0.50 \mathrm{BT}-0.29 \mathrm{BC}$ & 0.75 \\
\hline & 56 day & $\begin{aligned}+38.24 & -1.97 \mathrm{w} / \mathrm{cm}-0.89 \mathrm{~S} / \mathrm{A}+0.57 \mathrm{BT}-0.55 \mathrm{BC} \\
& +0.54(\mathrm{w} / \mathrm{cm} \cdot \mathrm{BT})-0.52(\mathrm{VMA} \cdot \mathrm{S} / \mathrm{A})\end{aligned}$ & 0.85 \\
\hline
\end{tabular}


The $\mathrm{w} / \mathrm{cm}$ had the greatest influence on investigated mechanical properties. The binder type (BT) had considerable effect on compressive strength and MOE. The long-term MOE response (28 days and 56 days) appeared to be significantly affected by S/A. In most cases, the use of VMA did not have significant effect on mechanical properties.

Based on the derived models for mechanical properties for the modeled region between -2 and +2 , the main findings can be summarized as follows:

- Compressive strength and MOE are shown, as expected, to increase as the decrease in w/cm; furthermore, the increase in binder content leads to a decrease in MOE.

- The increase in S/A has negative effect on MOE at 28 and 56 days (moist curing).

- Type HE cement and 20\% of Class F fly ash exhibit higher compressive strength and MOE at 28 and 56 days but lower mechanical properties at $18 \mathrm{~h}$ compared to Type MS cement.

\subsection{Evaluation of Statistical Models for Mechanical Properties}

The contour diagrams of the 28-day modulus of elasticity in Figure 4 illustrate the trade-offs between binder content and w/cm for mixtures made with Type MS and Type HE with 20\% fly ash binder and 0.42 and $0.58 \mathrm{~S} / \mathrm{A}$, corresponding to coded values of -2 and +2 . The VMA value is set to the central points. As indicated in Figure 4, for the same w/cm and binder content, the S/A and type of binder have no significant effect on MOE at 28 days. As expected, the increase in both binder content and w/cm decreases the MOE. For example, for SCC made with $500 \mathrm{~kg} / \mathrm{m}^{3}$ binder content, Type MS cement, and $0.58 \mathrm{~S} / \mathrm{A}$, the increase in $\mathrm{w} / \mathrm{cm}$ from 0.34 to 0.40 leads to the decrease of 28-day modulus of elasticity from 37 to $32.5 \mathrm{GPa}$, as shown in Figure $4 \mathrm{a}$.

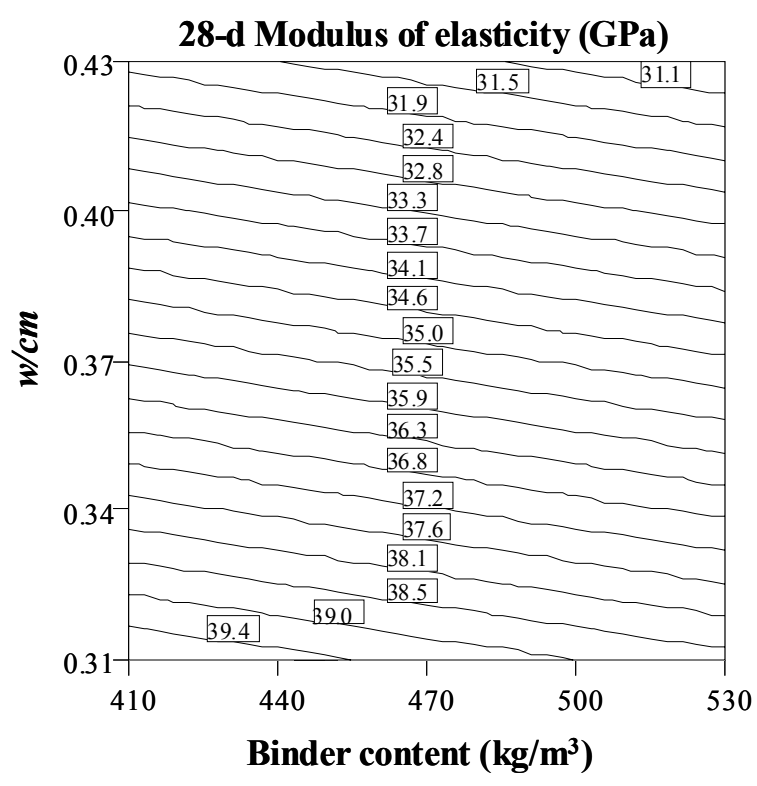

(a)

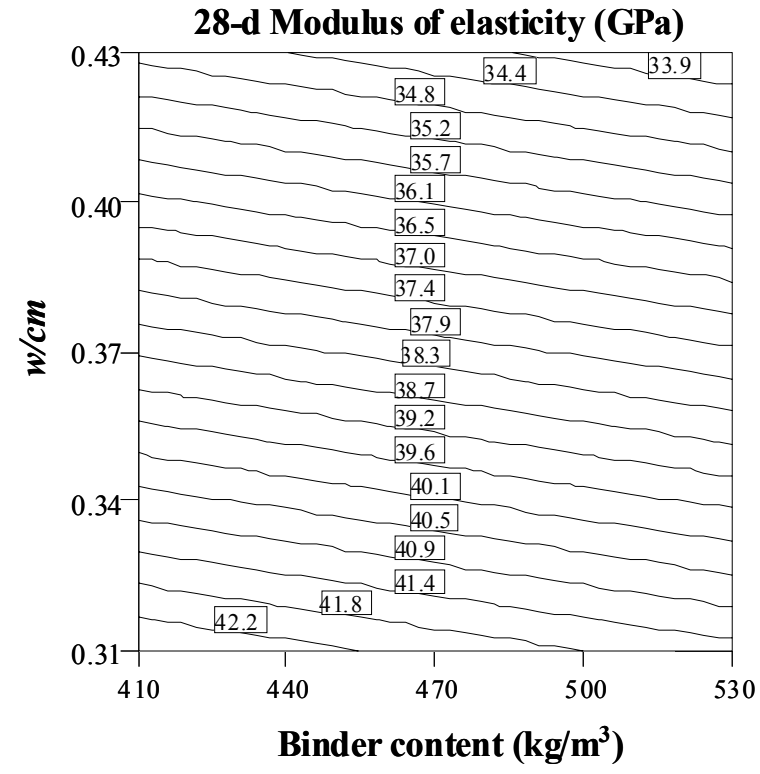

(b)

Figure 4. Cont. 


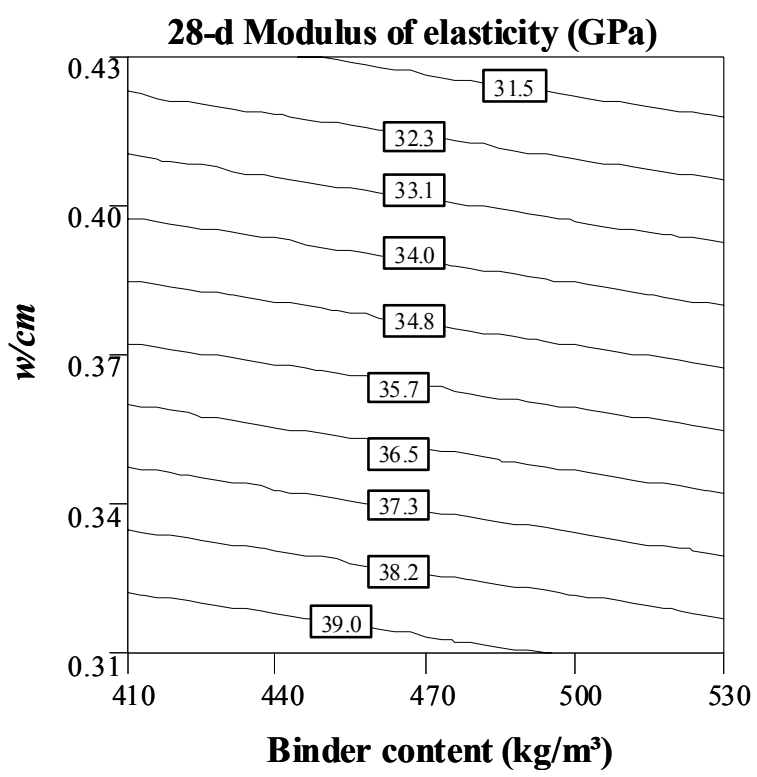

(c)

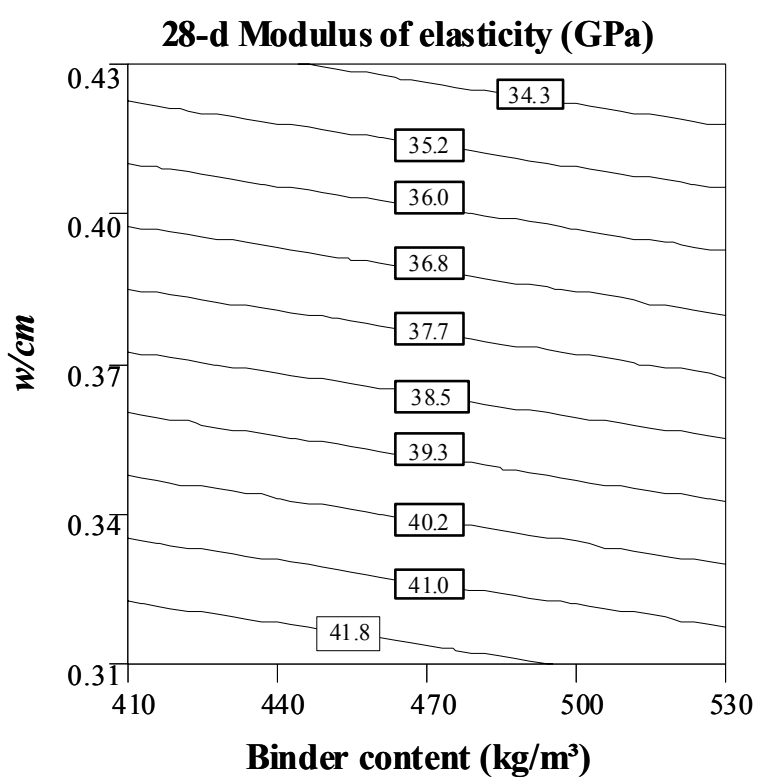

(d)

Figure 4. Binder content $-\mathrm{w} / \mathrm{cm}$ contour diagrams of 28-day modulus of elasticity $(\mathrm{VMA}=50 \mathrm{~mL} / 100 \mathrm{~kg} \mathrm{CM})$. (a) $\mathrm{S} / \mathrm{A}=0.58$, Type MS; (b) S/A = 0.42, Type MS; (c) $\mathrm{S} / \mathrm{A}=0.58$, Type HE $+20 \% \mathrm{FA}$; (d) $\mathrm{S} / \mathrm{A}=0.42$, Type HE $+20 \% \mathrm{FA}$.

\subsection{Derived Statistical Models for Autogenous and Drying Shrinkage}

Mean values and standard deviations for the autogenous and drying shrinkage responses and the calculated relative errors corresponding to $90 \%$ confidence limits are summarized in Table 9. The coefficients and Prob. $>|\mathbf{t}|$ values of the derived models for autogenous and drying shrinkage are presented in Table 10.

Table 9. Mean values and relative errors of central points ( $90 \%$ confidence limit).

\begin{tabular}{cccc}
\hline Property & Mean & $\begin{array}{c}\text { Standard } \\
\text { Deviation }\end{array}$ & $\begin{array}{c}\text { Relative Error * in 90\% } \\
\text { Confidence Limit, (\%) }\end{array}$ \\
\hline 7 days autogenous shrinkage, $\mu$ strain & 115 & 4.8 & 4.8 \\
28 days autogenous shrinkage, $\mu$ strain & 200 & 2.5 & 1.5 \\
56 days autogenous shrinkage, $\mu$ strain & 230 & 2.9 & 1.5 \\
28 days drying shrinkage, $\mu$ strain & 345 & 17.0 & 5.8 \\
112 days drying shrinkage, $\mu$ strain & 505 & 11.9 & 2.8 \\
250 days drying shrinkage, $\mu$ strain & 600 & 5.8 & 1.1 \\
\hline
\end{tabular}

* Relative error $=2.35 \frac{\sigma}{\bar{x} \sqrt{n}} \cdot 100(\%)$; where, $2.35=$ coefficient representing the $90 \%$ confidence interval for the Student's distribution for $n=4 ; \sigma=$ standard deviation; $n=$ number of observations; $\bar{x}=$ mean value of observations. 
Table 10. Parameter estimates of derived models for autogenous and drying shrinkage.

\begin{tabular}{|c|c|c|c|c|c|c|}
\hline \multirow{3}{*}{$\begin{array}{c}\text { Property } \\
\text { Model Type } \\
\text { Parameters } \\
\end{array}$} & \multicolumn{2}{|c|}{$\begin{array}{l}\text { Autogenous Shrinkage at } \\
7 \text { Days ( } \mu \text { strain) } R^{2}=0.92\end{array}$} & \multicolumn{2}{|c|}{$\begin{array}{c}\text { Autogenous Shrinkage at } \\
56 \text { Days ( } \mu \text { strain) } R^{2}=0.82\end{array}$} & \multicolumn{2}{|c|}{$\begin{array}{c}\text { Drying Shrinkage at } \\
7 \text { Days }\left(\mu \text { strain) } R^{2}=0.70\right.\end{array}$} \\
\hline & \multicolumn{2}{|c|}{ Linear Model } & \multicolumn{2}{|c|}{ Linear Model } & \multicolumn{2}{|c|}{ Linear Model } \\
\hline & Estimates & Prob. $>|\mathbf{t}|$ & Estimates & Prob. $>|\mathbf{t}|$ & Estimates & Prob. $>|\mathbf{t}|$ \\
\hline Intercept & +129.87 & - & +217.0 & - & +173.23 & - \\
\hline Binder content & NS * & NS & +8.33 & 0.100 & +16.21 & 0.068 \\
\hline $\mathrm{w} / \mathrm{cm}$ & -37.42 & 0.001 & -37.5 & 0.001 & -43.46 & 0.001 \\
\hline Binder type & +30.75 & 0.001 & +54.75 & 0.001 & NS & NS \\
\hline $\mathrm{BC} \cdot \mathrm{w} / \mathrm{cm}$ & -21.63 & 0.001 & -18.75 & 0.033 & NS & NS \\
\hline $\mathrm{BC} \cdot \mathrm{BT}$ & -15.88 & 0.001 & NS & NS & NS & NS \\
\hline $\mathrm{BC} \cdot \mathrm{S} / \mathrm{A}$ & +9.88 & 0.001 & +17.75 & 0.043 & NS & NS \\
\hline $\mathrm{BC} \cdot \mathrm{VMA}$ & NS & NS & NS & NS & -18.56 & 0.087 \\
\hline $\mathrm{w} / \mathrm{cm} \cdot \mathrm{VMA}$ & NS & NS & NS & NS & +20.69 & 0.058 \\
\hline $\mathrm{w} / \mathrm{cm} \cdot \mathrm{BT}$ & -20.13 & 0.001 & NS & NS & NS & NS \\
\hline Property & \multicolumn{2}{|c|}{$\begin{array}{c}\text { Drying shrinkage at } \\
28 \text { Days }\left(\mu \text { strain) } R^{2}=0.72\right.\end{array}$} & \multicolumn{2}{|c|}{$\begin{array}{c}\text { Drying shrinkage at } \\
112 \text { Days ( } \mu \text { strain) } R^{2}=0.82\end{array}$} & \multicolumn{2}{|c|}{$\begin{array}{c}\text { Drying shrinkage at } \\
250 \text { Days ( } \mu \text { strain) } R^{2}=0.73\end{array}$} \\
\hline Model Type & \multicolumn{2}{|c|}{ Linear Model } & \multicolumn{2}{|c|}{ Linear Model } & \multicolumn{2}{|c|}{ Linear Model } \\
\hline Parameters & Estimates & Prob. $>|\mathbf{t}|$ & Estimates & Prob. $>|t|$ & Estimates & Prob. $>|t|$ \\
\hline Intercept & +323.23 & - & +517.77 & - & +620.00 & - \\
\hline Binder content & +31.54 & 0.024 & +41.33 & 0.009 & +47.50 & 0.006 \\
\hline $\mathrm{w} / \mathrm{cm}$ & -45.71 & 0.002 & -36.25 & 0.019 & -39.17 & 0.021 \\
\hline $\mathrm{S} / \mathrm{A}$ & NS & NS & +26.58 & 0.078 & +29.75 & 0.072 \\
\hline $\mathrm{BC} \cdot \mathrm{VMA}$ & -28.19 & 0.091 & -44.38 & 0.019 & -51.00 & 0.015 \\
\hline $\mathrm{w} / \mathrm{cm} \cdot \mathrm{VMA}$ & +48.44 & 0.006 & +45.13 & 0.018 & +50.75 & 0.015 \\
\hline $\mathrm{w} / \mathrm{cm} \cdot \mathrm{BT}$ & +28.81 & 0.084 & +41.88 & 0.026 & NS & NS \\
\hline VMA BT & +30.81 & 0.066 & +42.63 & 0.024 & +47.63 & 0.022 \\
\hline
\end{tabular}

* NS: Not significant.

Based on the statistical models established in this investigation, the $\mathrm{w} / \mathrm{cm}$ had the most significant influence on autogenous and drying shrinkage at various ages. The type of binder had considerable effect on autogenous shrinkage. Drying shrinkage varied mainly with the binder content. The S/A value had considerable effect on drying shrinkage at 112 and 250 days. In most cases, VMA had a minor effect on the measured responses. The derived models are summarized in Table 11. The main findings from the statistical models within the -2 to +2 region are given as follows:

- Autogenous shrinkage of SCC decreases as w/cm increases.

- Increase in binder content leads to an increase in drying shrinkage.

- For a given binder content, drying shrinkage of concrete does not increase with $\mathrm{w} / \mathrm{cm}$. This is because the drying shrinkage measurement also includes autogenous shrinkage, which obviously decreases with the increase in $\mathrm{w} / \mathrm{cm}$.

- SCC made with Type HE cement and 20\% Class F fly ash develops higher autogenous shrinkage compared to concrete prepared with Type MS cement.

- Binder type and thickening-type VMA do not have a significant effect on drying shrinkage. 
Table 11. Derived statistical models for autogenous and drying shrinkage.

\begin{tabular}{|c|c|c|c|}
\hline Property & Age & Derived Equations & $R^{2}$ \\
\hline \multirow{2}{*}{$\begin{array}{c}\text { Autogenous } \\
\text { shrinkage, } \mu \text { strain }\end{array}$} & 7 days & $\begin{array}{l}+129.9-37.4 \mathrm{w} / \mathrm{cm}+30.8 \mathrm{BT}-21.6(\mathrm{BC} \cdot \mathrm{w} / \mathrm{cm}) \\
-20.1(\mathrm{w} / \mathrm{cm} \cdot \mathrm{BT})-15.9(\mathrm{BC} \cdot \mathrm{BT})+9.9(\mathrm{BC} \cdot \mathrm{S} / \mathrm{A})\end{array}$ & 0.92 \\
\hline & 56 days & $\begin{aligned}+217.0+54.8 \mathrm{BT}- & 37.5 \mathrm{w} / \mathrm{cm}+8.3 \mathrm{BC}-18.8(\mathrm{BC} \cdot \mathrm{w} / \mathrm{cm}) \\
+ & 17.8(\mathrm{BC} \cdot \mathrm{S} / \mathrm{A})\end{aligned}$ & 0.82 \\
\hline \multirow{4}{*}{$\begin{array}{c}\text { Drying } \\
\text { shrinkage, } \mu \text { strain }\end{array}$} & 7 days & $\begin{array}{c}+173.2-43.5 \mathrm{w} / \mathrm{cm}+16.2 \mathrm{BC}-18.6(\mathrm{BC} \cdot \mathrm{VMA}) \\
+20.7(\mathrm{w} / \mathrm{cm} \cdot \mathrm{VMA})\end{array}$ & 0.70 \\
\hline & 28 days & $\begin{aligned} & +323.2-45.7 \mathrm{w} / \mathrm{cm}+31.5 \mathrm{BC}+48.4(\mathrm{w} / \mathrm{cm} \cdot \mathrm{VMA}) \\
+ & 28.8(\mathrm{w} / \mathrm{cm} \cdot \mathrm{BT})-28.2(\mathrm{BC} \cdot \mathrm{VMA})+30.8(\mathrm{VMA} \cdot \mathrm{BT})\end{aligned}$ & 0.72 \\
\hline & 112 days & $\begin{array}{c}+517.8+41.3 \mathrm{BC}-36.3 \mathrm{w} / \mathrm{cm}+26.6 \mathrm{~S} / \mathrm{A}+45.1(\mathrm{w} / \mathrm{cm} \cdot \mathrm{VMA}) \\
-44.4(\mathrm{BC} \cdot \mathrm{VMA})+42.6(\mathrm{VMA} \cdot \mathrm{BT})+41.9(\mathrm{w} / \mathrm{cm} \cdot \mathrm{BT})\end{array}$ & 0.82 \\
\hline & 250 days & $\begin{array}{c}+620.0+47.5 \mathrm{BC}-39.2 \mathrm{w} / \mathrm{cm}+29.8 \mathrm{~S} / \mathrm{A}-51.0(\mathrm{BC} \cdot \mathrm{VMA}) \\
+50.8(\mathrm{w} / \mathrm{cm} \cdot \mathrm{VMA})+47.6(\mathrm{VMA} \cdot \mathrm{BT})\end{array}$ & 0.73 \\
\hline
\end{tabular}

\subsection{Evaluation of Statistical Models for Visco-Elastic Properties}

Autogenous shrinkage contour diagrams at 56 days are presented in Figure 5 to show trade-offs between w/cm and S/A for mixtures made with Type MS cement and Type HE cement and 20\% fly ash. The binder content and VMA content are set at $530 \mathrm{~kg} / \mathrm{m}^{3}$ and $100 \mathrm{~mL} / 100 \mathrm{~kg} \mathrm{CM}$, respectively. As expected, for a constant $\mathrm{S} / \mathrm{A}$ value, an increase in $\mathrm{w} / \mathrm{cm}$ decreases autogenous shrinkage. Furthermore, for SCC made with the same S/A and w/cm, the use of Type HE cement and 20\% fly ash results in higher autogenous shrinkage than mixtures prepared with Type MS cement.

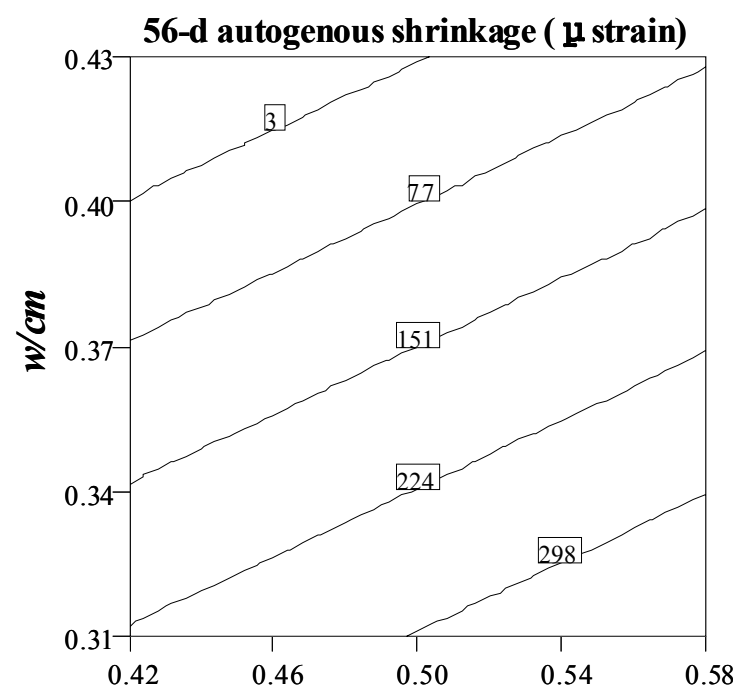

S/A

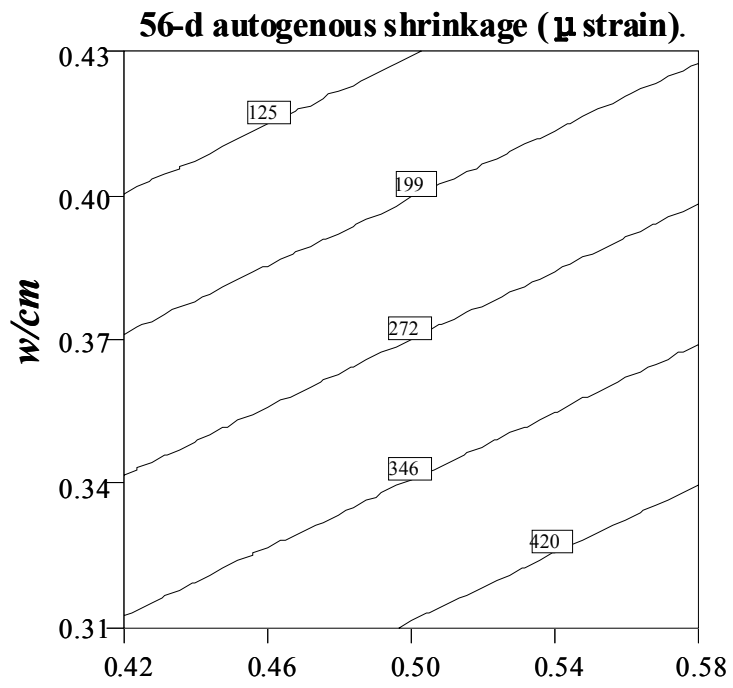

S/A

(b)

Figure 5. S/A-w/cm contour diagrams of 56-day autogenous shrinkage (Binder content $=$ $530 \mathrm{~kg} / \mathrm{m}^{3}, \mathrm{VMA}=100 \mathrm{~mL} / 100 \mathrm{~kg} \mathrm{CM}$ ). (a) Type MS; (b) Type HE $+20 \%$ FA.

The drying shrinkage contour diagrams at 250 days in Figure 6 illustrate the trade-offs between binder content and S/A for mixtures made with Type MS and Type HE cement with $20 \%$ fly ash. The 
$\mathrm{W} / \mathrm{cm}$ and VMA values are set to the central points for both mixtures. In general, the increase in binder content leads to an increase in drying shrinkage. As illustrated in Figure 6a,b, for a constant S/A of 0.50 , an increase in binder content from 440 to $500 \mathrm{~kg} / \mathrm{m}^{3}$ leads to an increase in the 250 -day drying shrinkage values from 590 to $690 \mu$ strain and from 580 to $680 \mu$ strain, for mixtures made with Type MS and Type HE with 20\% fly ash binder, respectively. Moreover, SCC made with higher S/A exhibits higher drying shrinkage after 250 days of drying. No significant differences were found for SCC made with the same binder content and S/A but different binder types.

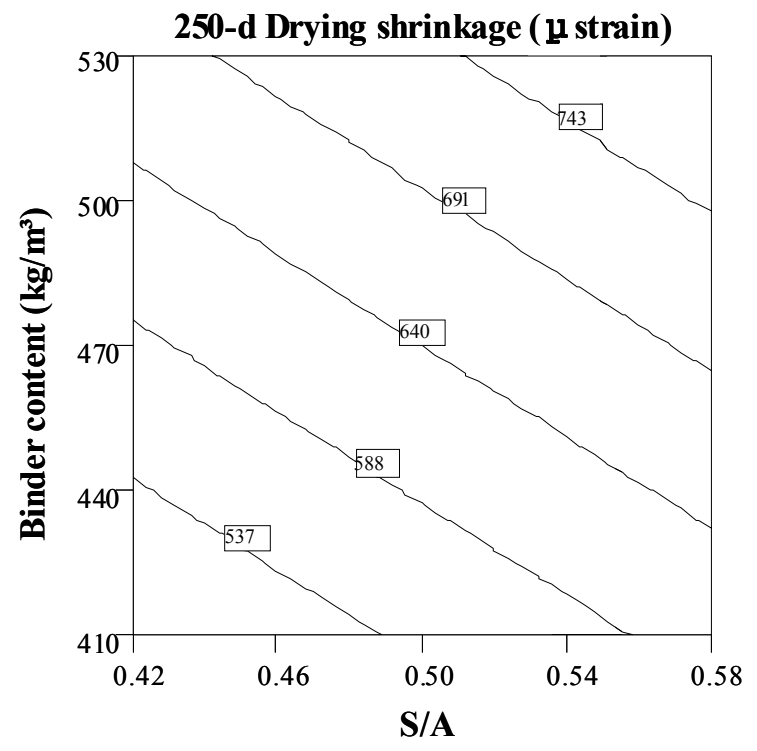

(a)

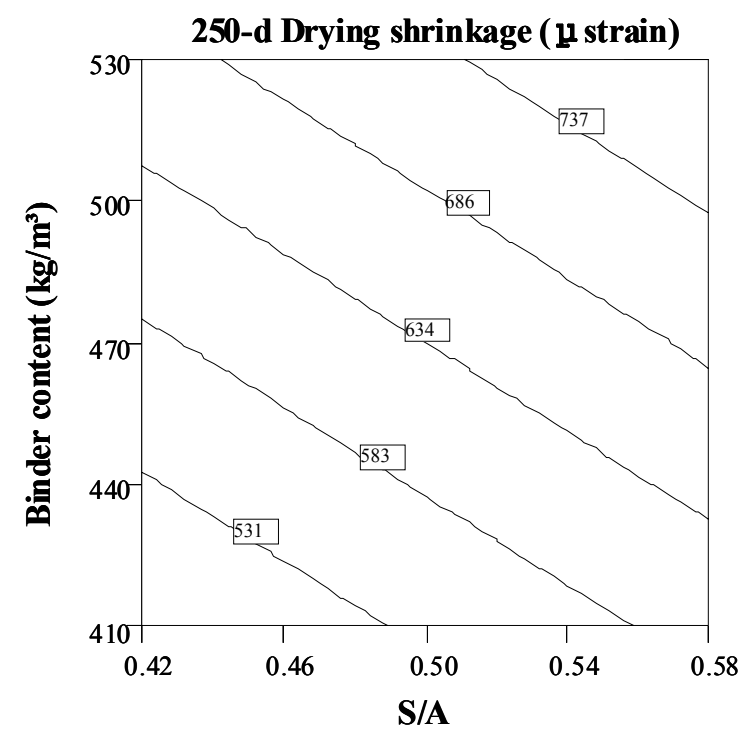

(b)

Figure 6. Binder content-S/A contour diagrams of 250-day drying shrinkage $(\mathrm{w} / \mathrm{cm}=0.37$, $\mathrm{VMA}=50 \mathrm{~mL} / 100 \mathrm{~kg} \mathrm{CM}$ ). (a) Type MS; (b) Type HE + 20\%FA.

\subsection{Extension of the Statistical Models}

In this investigation, the $2^{5-1}$ fractional factorial design was expanded to include eight additional mixtures where each variable was adjusted separately at the extreme $\alpha$ value of -2 and +2 , with other variables maintained at the 0 central points. The variations of $R^{2}$ values within the -1 and +1 and -2 and +2 modeled regions for the mechanical and visco-elastic property responses are summarized in Table 12. The $R^{2}$ values within the -1 and +1 region are obtained from the previous investigations [15]. The correlation coefficient $R^{2}$ values are shown to decrease when the modeled region varies from the $(-1,+1)$ range to the $(-2,+2)$ range. This is because the error in predicting each response increases with the deviation from the center of modeled region. Deviation from central points has a negative influence on the degree of prediction of the various models.

Table 12. Variations of $R^{2}$ values with different modeled regions.

\begin{tabular}{|c|c|c|c|c|c|c|c|}
\hline \multirow{2}{*}{ Modeled Region } & \multicolumn{2}{|c|}{ Autogenous Shrinkage } & \multicolumn{2}{|c|}{ Drying Shrinkage } & \multirow{2}{*}{$\begin{array}{c}\text { Compressive Strength } \\
56 \text { Days }\end{array}$} & \multicolumn{2}{|c|}{ MOE } \\
\hline & 7 Days & 56 Days & 28 Days & 112 Days & & $18 \mathrm{~h}$ & 56 Days \\
\hline$-1,+1$ & 0.96 & 0.93 & 0.78 & 0.96 & 0.87 & 0.89 & 0.87 \\
\hline$-2,+2$ & 0.92 & 0.82 & 0.72 & 0.82 & 0.79 & 0.73 & 0.85 \\
\hline
\end{tabular}


The accuracy of predicted responses is affected by deviation from the set of materials used in establishing the models. However, the models can still be used for mixture optimizations and simulations despite changes in material characteristics, since such materials have limited effect on the prediction accuracy of the modeled responses. A logical design approach would be to use the existing model to predict the optimal design, and then run selected tests to quantify the influence of the new binder on the model. A limited number of mixtures can be prepared to adjust the existing model to take into consideration the influence of the newly considered material types on concrete properties relevant to the quality of SCC.

\section{Conclusions}

The statistical models established using a factorial design approach can be used to quantify the effects of mixture parameters and their coupled effects on the fresh, mechanical, and visco-elastic properties of SCC. In this investigation, a factorial design was adopted within the model regions of -2 and +2 to mathematically model the influence of five parameters on compressive strength, modulus of elasticity, autogenous shrinkage, and drying shrinkage of prestressed SCC. Based on the statistical models derived from the factorial design, the following conclusions can be drawn:

- In terms of mechanical properties, w/cm had the highest effect on compressive strength and modulus of elasticity; moreover, the content and type of binder had a considerable effect on mechanical properties. The modulus of elasticity was also affected by the S/A, and VMA content did not show a significant effect on mechanical properties.

- In terms of visco-elastic properties, w/cm was found to be the most significant factor, and the binder type also had a significant effect on autogenous shrinkage. Furthermore, drying shrinkage varied mainly with the binder content; in most cases, the VMA had a minor effect on autogenous and drying shrinkage.

- Based on the results from the derived models that were extended to the -2 to +2 region, no significant difference can be found between the statistical models $(-1$ to +1$)$ and those extended to -2 to +2 . In order to eliminate the outer regions approaching the edges of the modeled region and to minimize the prediction error, the model region can be limited to coded values of -1.5 to +1.5 .

\section{Acknowledgments}

The authors gratefully acknowledge the financial support provided by the Transportation Research Board of the National Academies of the United States of America for the National Cooperative Highway Research Program (NCHRP) Project 18-12, the National Natural Science Foundation of China (No. 51278306), and the Science Industry Trade and Information Technology Commission of Shenzhen Municipality (No. GJHZ20120614144906248).

\section{Author Contributions}

W.J. Long designed and conducted the core experiments and wrote the draft of the manuscript. K. Khayat and F. Xing analyzed statistical models using G. Lemieux's measured data. K. Khayat 
designed the project and W.L. Wang supervised the research. All authors contributed to the analysis to produce results and conclusions and revised the paper.

\section{Conflicts of Interest}

The authors declare no conflict of interest.

\section{References}

1. Okamura, H.; Ouchi, M. Self-compacting concrete. J. Adv. Concr. Technol. 2003, 1, 5-15.

2. Self-Consolidating Concrete; ACI Committee 237R-07; American Concrete Institute: Farmington Hills, MI, USA, 2007; p. 30.

3. European Federation of National Trade Associations (EFNARC). The European Guidelines for Self-Compacting Concrete; EFNARC: Surrey, UK, 2005; p. 63.

4. Nehdi, M.L. Only tall things cast shadows: Opportunities, challenges and research needs of self-consolidating concrete in super-tall. Constr. Build. Mater. 2013, 48, 80-90.

5. Phelan, W.S. Self-consolidating concrete (SCC): Today's challenge and tomorrow's prosperity. In Proceedings of the 5th North American Conference on Design and Use of Self-Consolidating Concrete, Chicago, IL, USA, 12-15 May 2013; p. 4.

6. Pawlikowski, J.J.; Rankin, D.S.; Young, B.S. SCC in iconic supertall towers: Trump tower, Chicago, USA; Infinity Tower, Dubai, UAE; Burj Khalifa, Dubai, UAE. In Proceedings of the 5th North American Conference on Design and Use of Self-Consolidating Concrete, Chicago, IL, USA, 12-15 May 2013; p. 11.

7. Juvas, K. Experiences of working with self-compacting concrete in the precast industry. In Proceedings of the 5th International RILEM Symposium on Self-Compacting Concrete, Ghent, Belgium, 3-5 September 2007; pp. 933-938.

8. Camacho, R.; Afif, R.; Corona, G.; Roman, H.; Sanchez, M. Applications of SCC technology for precast/prestressed elements: The Mexican experiences. In Proceedings of the 5th International RILEM Symposium on Self-Compacting Concrete, Ghent, Belgium, 3-5 September 2007; pp. 1071-1078.

9. Domone, P.L. Self-compacting concrete: An analysis of 11 years of case studies. Cem. Concr. Comps. 2006, 28, 197-208.

10. Naito, C.; Hoover, M. Applicability of self-consolidating concrete for use in precast bridge beam construction. In Proceedings of the Combining the Second North American Conference on the Design and Use of Self-Consolidating Concrete and the Fourth International RILEM Symposium on Self-Compacting Concrete, Chicago, IL, USA, 30 October-2 November 2005.

11. Long, W.J.; Khayat, K.H.; Lemieux, G.; Hwang, S.D.; Han, N.X. Performance-based specifications of workability characteristics of prestressed, precast self-consolidating concrete-A North American prospective. Materials 2014, 7, 2474-2489.

12. Khayat, K.H. Workability, testing, and performance of self-consolidating concrete. ACI. Mater. J. 1996, 96, 346-353.

13. Long, W.J.; Khayat, K.H.; Hwang, S.D. Mechanical properties of prestressed self-consolidating concrete. Mater. Struct. 2013, 46, 1473-1487. 
14. Long, W.J.; Khayat, K.H. Creep of prestressed self-consolidating concrete. ACI. Mater. J. 2011, $108,476-484$.

15. Long, W.J.; Lemieux, G.; Hwang, S.D.; Khayat, K.H. Statistical models to predict fresh and hardened properties of self-consolidating concrete. Mater. Struct. 2012, 45, 1035-1052.

16. Khayat, K.H.; Ghezal, A.; Hadriche, M.S. Utility of statistical models in proportioning self-consolidating concrete. Mater. Struct. J. 2000, 33, 338-344.

17. Lotfy, A.; Hossain, K.M.A.; Lachemi, M. Application of statistical models in proportioning lightweight self-consolidating concrete with expanded clay aggregates. Constr. Build. Mater. 2014, 65, 450-469.

18. Filho, F.M.A.; Barragán, B.E.; Casas, J.R. Debs ALHCE, Hardened properties of self-compacting concrete-a statistical approach. Constr. Build. Mater. 2010, 24, 1608-1615.

19. Kanadasan, J.; Razak, H.A. Mix design for self-compacting palm oil clinker concrete based on particle packing. Mater. Des. 2014, 56, 9-19.

20. Khaleel, O.R.; Razak, H.A. Mix design method for self-compacting metakaolin concrete with different properties of coarse aggregate. Mater. Des. 2014, 53, 691-700.

21. Dinakar, P.; Manu, S.N. Concrete mix design for high strength self-compacting concrete using metakaolin. Mater. Des. 2014, 60, 661-668.

22. Sonebi, M.; Bassuoni, M.T. Investigating the effect of mixture design parameters on pervious concrete by statistical modeling. Constr. Build. Mater. 2013, 38, 147-154.

23. Sonebi, M.; Cevik, A. Prediction of fresh and hardened properties of self-consolidating concrete using neurofuzzy approach. J. Mater. Civ. Eng. 2009, 21, 672-679.

24. Sonebi, M. Applications of statistical models in proportioning medium-strength self-consolidating concrete. ACI. Mater. J. 2004, 101, 339-346.

25. Nunes, S.; Milheiro-Oliveira, P.; Coutinho, J.S.; Figueiras, J. Robust SCC mixes through mix design. J. Mater. Civ. Eng. 2013, 25, 183-193.

26. Bassuoni, M.T.; Nehdi, M.L. Neuro-fuzzy based prediction of the durability of self-consolidating concrete to various sodium sulfate exposure regimes. Comput. Concr. 2008, 5, 573-597.

27. Montgomery, D.C. Design and Analysis of Experimental, 8th ed.; Wiley: Hoboken, NJ, USA, 2007; p. 752.

28. Standard Method of Test for Sieve Analysis of Fine and Coarse Aggregates; AASHTO T-27; American Association of State Highway Transportation Officials (AASHTO): Washington, DC, USA, 2011; p. 8.

29. Standard Specification for Chemical Admixtures for Concrete; ASTM C494/C494M-13; American Society for Testing and Materials: West Conshohocken, PA, USA, 2013.

30. Standard Practice for Making and Curing Concrete Test Specimens in the Laboratory; ASTM C192-14/C192M-14; American Society for Testing and Materials: West Conshohocken, PA, USA, 2014.

31. Standard Test Method for Compressive Strength of Cylindrical Concrete Specimens; ASTM C39/C39M-14a; American Society for Testing and Materials: West Conshohocken, PA, USA, 2014.

32. Standard Test Method for Static Modulus of Elasticity and Poisson's Ratio of Concrete in Compression; ASTM C469/C469M-14; American Society for Testing and Materials: West Conshohocken, PA, USA, 2014. 
33. Standard Test Method for Length Change of Hardened Hydraulic-Cement Mortar and Concrete; ASTM C157/C157M-08; American Society for Testing and Materials: West Conshohocken, PA, USA, 2008.

34. LRFD Bridge Design Specifications, 4th ed.; American Association of State and Highway Officials: Washington, DC, USA, 2007; p. 1518.

35. Design of Concrete Structures; CAN/CSA-A23.3-04(R2010); Canadian Standards Association (CSA): Rexdale, ON, USA, 2004; p. 258.

36. Interim Guidelines for the Use of Self-Consolidating Concrete in PCI Member Plants; Precast/Prestressed Concrete Institute: Chicago, IL, USA, 2003; p. 148.

(C) 2015 by the authors; licensee MDPI, Basel, Switzerland. This article is an open access article distributed under the terms and conditions of the Creative Commons Attribution license (http://creativecommons.org/licenses/by/4.0/). 